\title{
LIBERALIZATION, GLOBALIZATION AND THE DYNAMICS OF DEMOCRACY IN INDIA
}

\section{M. NACHANE}

ESRC-ICSSR Fellow, Asia Research Centre

LSE India Observatory 


\title{
ASIA RESEARCH CENTRE WORKING PAPER 32
}

\section{LIBERALIZATION, GLOBALIZATION AND THE DYNAMICS OF DEMOCRACY IN INDIA*}

\author{
Written by: D. M. NACHANE
}

Dilip Nachane visiting ESRC-ICSSR Fellow at the LSE India Observatory, and Hon. Sr. Fellow at the ISAS, NUS, Singapore. He has held a number of distinguished positions in his career including Director of the Indira Gandhi Institute of Development Research, Mumbai, India (2007-2010), Director, Department of Economics, University of Mumbai (1993-1999) and Hon. Director, Western Regional Centre (Indian Council of Social Science Research) (1999-2003). He has also lectured at a number of universities in UK, Europe and North America including the University of British Columbia (Canada), University of Zurich (Switzerland), University of Ulster, University of Magdeburg (Germany) etc. He has also been a Sr. Hallsworth Fellow at the University of Manchester (UK), a Fulbright Fellow at the University of Texas at Austin (US) and Jean Monnet Fellow at the European University Institute (Florence, Italy). He has published several books and research articles in the areas of Econometric Theory, Banking \& Finance, Macroeconomics, Development Economics etc. He is also currently a member of the Reserve Bank of India's Technical Advisory Committee on Monetary Policy.

June 2010

Copyright $@$ C Dilip Nachane, 2010

All rights reserved. Apart from any fair dealing for the purpose of research or private study, or criticism or review, no part of this publication may be reproduced, stored in a retrieval system or transmitted in any form or by any means without the prior permission by the publisher of the author.

For further information, please contact:

Asia Research Centre (ARC)

London School of Economics \& Political Science

Houghton Street

London WC2A 2AE

www.lse.ac.uk/asiaresearchcentre

E-mail: Asia.Research.Centre@lse.ac.uk

\footnotetext{
- I wish to thank Pranab Bardhan, Roger Montgomery and Ruth Kattumuri for their valuable comments. Responsibility for the views expressed, as well as any shortcomings and errors, lies solely with the author. The work was rendered possible by a joint grant from the ESRC (UK) and the ICSSR (India), for which I am grateful.
} 


\title{
LIBERALIZATION, GLOBALIZATION AND THE DYNAMICS OF DEMOCRACY IN INDIA
}

\begin{abstract}
In the closing decades of the twentieth century there has been an almost complete intellectual triumph of the twin principles of marketization (understood here as referring to the liberalization of domestic markets and freer international mobility of goods, services, financial capital and perhaps, more arguably, labour) and democratization. A paradigm shift of this extent and magnitude would not have occurred in the absence of some broad consensus among policymakers and (sections of) intellectuals around the globe on the desirability of such a change. There seems to be a two-fold causal nexus between marketization and democracy. The first is more direct, stemming from the fact of both systems sharing certain values and attitudes in common. But there is also a second more indirect chain from marketization to democracy, which is predicated via three sub-chains (i) from marketization to growth, (ii) from growth to overall material development welfare and (iii) from material development to social welfare and democracy. We examine each of these sub-links in detail with a view to obtaining a greater understanding of the hypothesized role of free markets in promoting democracies. In the later part of the paper we examine the socio-economic outcomes governing the quality of democracy in a specifically Indian context.
\end{abstract}

\section{INTRODUCTION}

A future historian writing of our times, would most likely describe the closing decades of the twentieth century as marking the complete intellectual triumph of the three principles of :

(i) Marketization: This term usually refers to the liberalization of domestic markets from the extensive government controls, which prevailed in many LDCs and EMEs (and even some advanced economies) in the decades prior to the 1980s.

(ii) Globalization : This implies freer international mobility of goods, services, financial capital and perhaps, more arguably, labour by the dismantling of the regime of extensive and high tariffs, quotas, current and capital account restrictions which had been in place since the end of World War II.

(iii) Democratization : This term is used to characterize the process by which from the mid-1980s, several autocratic regimes were replaced (either precipitously as in the case 
of the former Soviet Bloc or more gradually as in the case of several Asian economies) by regimes granting greater political liberty to its citizens.

While even a summary description of the diverse controversies underpinning this change of outlook in favour of free and open markets, could fill several volumes, one fact clearly stands out viz. That a paradigm shift of this extent and magnitude would not have occurred in the absence of some broad consensus ${ }^{1}$ among policymakers and (sections of) intellectuals around the globe on the desirability of such a change. Such a consensus essentially revolved around six key principles:

(i) Democracy is an "absolute good" i.e. desirable for its own sake and an important component of individual and social welfare ( Sen (2007)).

(ii) Higher levels of economic development are usually associated with increased democratization

(iii) Free markets are a necessary and sufficient prerequisite for economic growth (and development) in LDCs.

(iv) Economic growth enhances social welfare, so that there is a positive feedback from free markets to democracy, via the growth and welfare enhancing effects of free markets.

(v) Democracy is also growth enhancing, so that in a sense, democracy may be regarded as self-sustaining

(vi) Democracy is an important impetus for marketization, so that democracy, growth and free markets may be regarded as constituting a "virtuous cycle" each lending strength to the other. 


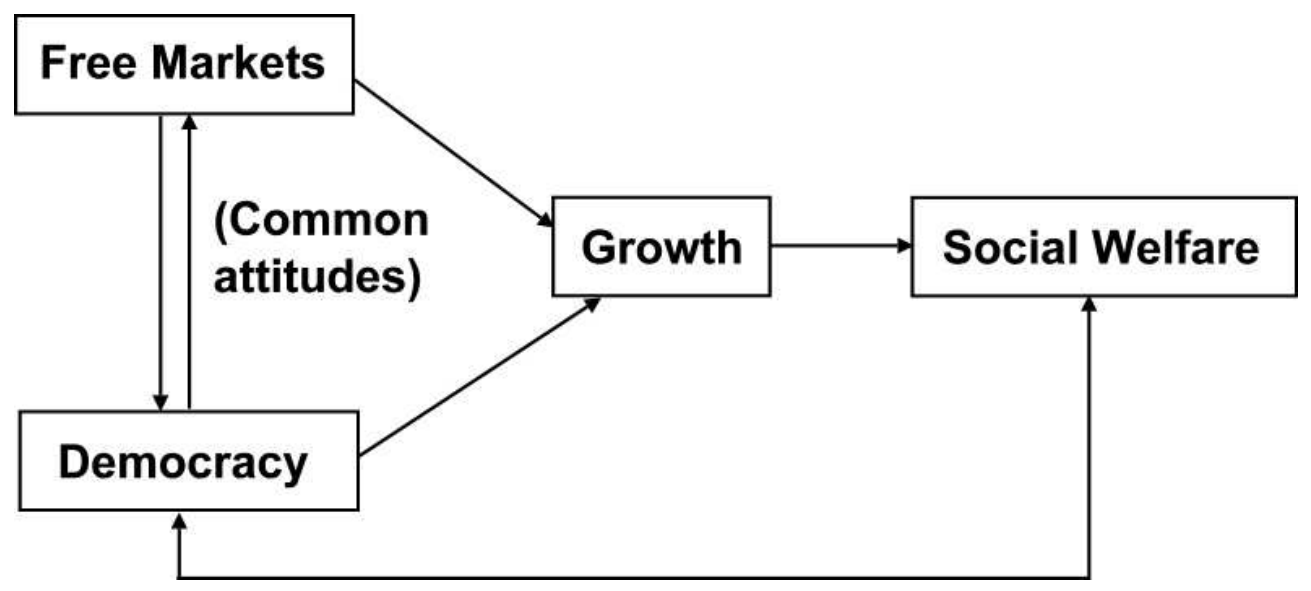

FIGURE 1

Of these, the first principle (that democracy is a desirable public good) is now almost universally accepted without qualification, though there are often disagreements about the precise form of democracy that is appropriate for a country ${ }^{2}$.

Over the other five tenets, however, there is considerable room for controversy and we propose here to critically appraise the analytical basis of each of these, using the Indian liberalization experience as a point of reference. ${ }^{3}$

The plan of our paper is as follows. The next two sections discuss some of the basic features of democracy and capitalism. As Figure 1 indicates, there is a two-fold causal nexus between marketization and democracy. The first is more direct, stemming from the fact of both systems sharing certain values and attitudes in common. This constitutes the subject matter of Section IV. But there is also a second more indirect chain from marketization to democracy, which is predicated via two sub-chains (i) from marketization to growth (and presumably to overall material development ${ }^{4}$ ) and (ii) from material development to social welfare and democracy. We examine each of these sublinks in some detail (Sections V and VI ), with a view to obtaining a greater understanding of the hypothesized role of free markets in promoting democracies. Section VII delineates certain general features of Indian democracy and outlines the 
rationale for focusing on outcomes in adjudging its quality. Section VIII discuss the three important outcomes (viz. the triad of growth, poverty and inequality, environment and natural resources, and corruption). The procedural conditions for democracy are examined in the Indian context in Section IX. Finally an attempt is made to gather our main conclusions and indicate potential directions of future work in Section X.

\section{DEMOCRACY : CHARACTERISTICS \& SOCIETAL PRERQUISITES}

\section{II.1 BASIC CHARACTERISTICS}

The lack of agreement on a suitable definition of democracy, stands in stark contrast to the almost universal belief in its desirability. Realizing the futility of searching for a generally acceptable definition of democracy, political thinkers have instead focused on the description of (what they view as ) the essential features of a democratic system, and the institutions and processes underpinning such systems (Bollen (1990), Cammack (1997) etc.).

The three basic requirements of a democracy are usually identified as (i) participation (ii) political competition and (iii) the existence of a constitutional mechanism providing for periodic changes of government.

Participation implies that individual political preferences matter for government decisions. ${ }^{5}$ Another vital dimension of democracy is political competition, which institutionalizes mechanisms for reaching political decisions (usually via a majority rule or occasionally some other consensual principle), in a manner which minimizes the potential for concentration of political power in the hands of any specific group (e.g. a military or ethnic faction, a business class, or a religious sect $)^{6}$. The third essential component of a representative democracy rests on a constitutional mechanism for periodic change of government. This ability to choose among alternate contenders for political office is supposed to result in an optimal arrangement for societal decision- 
making, in which majority rule becomes the abiding principle by which conflicting interests are resolved (Weber (1946) and Schumpeter (1943, [1987 ed.])

\section{2 SOCIAL PREREQUISITES}

The modern literature on the societal prerequisites of democracy often takes as its starting point the, by now, classic article of Lipset (1959). His major conclusions (backed with some empirical justification) may be summarized in the following table (adapted with some modifications from Lipset (1959) p. 105), where the requisites for democracy are shown in the left-hand column, whereas the consequences of democracy are shown in the right-hand column. Most of the consequences also appear in the requisites column, indicating a positive feedback relationship. However some of the consequences, have the potential to undermine democracy in the long run (and these have been indicated with an asterix $(*))$

\section{TABLE}

\begin{tabular}{|ll|ll|}
\hline \multicolumn{2}{|c|}{ Requisites For Democracy } & \multicolumn{2}{|c|}{ Consequences of Democracy } \\
\hline (i) & Industrialization & (i) & Mass society (*) \\
(ii) & Urbanization & (ii) & Bureaucracy (*) \\
(iii) & Education & (iii) & Education \\
(iv) & Literacy & (iv) & Literacy \\
(v) & Capitalist Mode Of Production & (v) & Political Apathy (*) \\
(vi) & Egalitarian Value System & (vi) & Egalitarian Value System \\
(vii) & Open Class System (i.e. Inter & (vii) & Open Class system \\
& Class Mobility) & & \\
(viii) & High Participation in Voluntary & & \\
& Organizations & & \\
\hline
\end{tabular}

In recent years, political thinkers have elaborated considerably on the basic Lipset scheme, primarily by focusing on democratic rights such as freedom of speech, travel 
and emigration, right to property, the special rights of religious and other minorities etc.( Diamond \& Plattner (1993), Neher \& Marlay (1995), etc.). There has, by now, emerged a burgeoning literature on the empirical correlates of democracy, designed to examine the relative importance of economic vis-à-vis social, cultural, religious, ethnic and other determinants of democracy (e.g. Rueschemeyer (1991), Roemer (1995), Przeworski \& Limongi (1993), Ravich (2000) etc.).

\section{CAPITALISM : ALTERNATIVE TAXONOMIES}

One of the remarkable features of the entire debate surrounding the issue of reforms in LDCs and EMEs is a complete lack of attention to the kind of capitalist system that was being projected to replace the older system of heavily state-regulated markets. The importance of the issue derives from the fact that the role of markets (and hence the socio-economic effects of the transformation) would crucially depend on the type of capitalist system that emerged as an outcome of the reforms process. At least three taxonomies of capitalism have been suggested in the recent literature.

1. Hall \& Soskice (2001) differentiate between liberal market economies (LMEs) and coordinated market economies (CMEs) with the U.S. serving as the paradigmatic illustration of the former and Germany and Japan of the latter.

2. Amable (2003) has a five-fold taxonomy - market-based capitalism (U.S., U.K., Australia, Canada), Continental European/Rhinish model (Germany, France, Belgium, Austria), Mediterranean(Italy, Spain, Portugal, Greece), Welfare-statist (Scandinavian countries) and Meso-Corporatist (Asia).

3. Baumol, Litan and Schramm (2007) adopt a more standard taxonomy distinguishing between oligarchic, state-guided, managerial and entrepreneurial varieties of capitalism.

A fact universally recognized but universally overlooked, is that almost all the virtues attributed to the role of markets by neo-classical economic analysis apply only to an ideal 
form of capitalism characterized by perfect market competition, free flow of information, absence of monopoly power and a minimalist state. Thus in the above three taxonomies the varieties of capitalism which have a modicum of resemblance to this ideal are the LME (Hall \& Soskice), the market-based model (Amable) and the entrepreneurial model (Baumol et al). Our use of the term capitalism in this paper will thus usually connote a system whose features closely approximate those of one of these systems.

\section{DEMOCRACY \& CAPITALISM : A COMMON SYSTEM OF VALUES ?}

There is a strong undercurrent in Western liberal philosophy, which views capitalism ${ }^{7}$ and democracy as braided in an irrevocable historical nexus. This position finds its clearest and strongest expression in the writings of three influential economists viz. Joseph Schumpeter (1987 ed.), F. Hayek (1944, 1960) and Milton Friedman (1963). Differences of detail and methodological controversies apart, all three writers are unanimous in their assertion that capitalism and democracy are inseparable and mutually causal, through a common system of values characterizing economic and political freedom. ${ }^{8}$ The fundamental core of beliefs revolves around the enshrinement of three key elements - private property, market competition and Adam Smith's invisible hand. Both share the common philosophy of "free will of the individual, imperfectability of human beings, primacy of private values and property .... the suspicion of government or any other agglomeration of power " (Weitzman (1993), p.314). From this, the conclusion seems inevitable that there is a natural isomorphism between the philosophies of democracy and capitalism ${ }^{9}$, and neither can flourish in the absence of the other.

In recent years, however, researchers have approached the issues with a more open mind, which assumes additional significance in the wake of the cataclysmic events culminating in the fall of Soviet communism. Their major premise is that the attitudes supporting democracy are conceptually distinct from those favouring markets. Dahl (1989), for example, has identified a list of social values as being conducive to democratic development: 
(i) belief in the legitimacy of democratic institutions such as public contestation and electoral participation

(ii) beliefs about authority relationships between government organizations and citizens

(iii) confidence in the capacity of the government to deal effectively with national problems

(iv) political and interpersonal trust

(v) belief in the possibility and desirability of political cooperation and

(vi) belief in conflict resolution among contending social groups through democratic mechanisms

Similarly Shiller et al (1991) have attempted to assess social attitudes that foster market behaviour, and prominent among these are :

(i) the fairness of price changes, and in particular whether it is perceived as legitimate for sellers to raise prices in response to demand

(ii) attitudes towards income inequality

(iii) attitudes towards incentive schemes for workers

(iv) resistance to the charging of interest on loans

(v) attitudes towards entrepreneurship

(vi) attitudes towards speculators and

(vii) an understanding of the rationale of compensated price changes

Once it is recognized that the values at the basis of democracy and markets are distinct, then the irrevocable causal connection between the two, that is central to Schumpeter, Hayek and Friedman is no more automatic, unless it can be shown that the two sets of values are mutually reinforcing, or stem from a deeper set of common values. Since at the purely theoretical level, a resolution of this question may be problematic, researchers have turned their attention to empirical approaches based on surveys. The issue has obtained a fresh lease of life with the emergence of various republics of the former USSR. The new "transformation economies" have provided a fertile ground for testing 
several key economic and political hypotheses, bearing on people's attitudes to democracy and markets. Researchers, basing their theories on attitudinal surveys such as those conducted by Finifter \& Mickiewicz (1992), Duch (1993), Reisinger et al (1994) etc., have come up with several interesting perceptions. Particularly interesting is the conclusion that seems to be emerging fairly robustly across the surveys that commitment to democratic values ( in the European part of the former USSR) was often weaker than the desire for a change in the economic system. Democracy was seen as of value only to the extent that the political change seemed to be necessary for initiating economic reform.

Thus, it is somewhat questionable whether a direct link between democracy and capitalism can be ascribed as confidently and as forcefully as postulated in much of the standard literature. We now turn to an examination of the indirect link between capitalism and democracy via growth and social welfare (see Section I).

\section{CAPITALISM \& GROWTH}

The first issue that needs to be explored is the relationship between capitalism and growth. It is reasonably clear that in much of neo-liberal writings, capitalism is being perceived as supportive of growth rather than a precondition of growth, ${ }^{10}$ and therefore we focus only on the unidirectional causal link from capitalism to growth.

The perception of a benevolent link between capitalism, economic growth, civil society and social welfare in general is attributable to the intellectual ascendancy of neo-classical economics as the mainstream view in recent years (post-1970). It was perhaps inevitable that in the light of this intellectual triumph, neo-classical economics should spill over its academic boundaries and enter the arena of economic policy. The neo-liberal ideology, which underpinned the liberalization wave of the 1980s in LDCs and EMEs and has underlain many of the recommendations of the IMF and World Bank on structural adjustments (the so-called Washington consensus), is essentially a bastardized version of neo-classical economics (in a sense to be made precise below). 
The major theoretical conclusions of neo-classical economics are encapsulated in two classic theorems. The first of these is the basic result that complete perfectly competitive markets lead to Pareto efficient outcomes, while the second is a partial converse to the first asserting that any Pareto efficient outcome (including those which are distributively just) can be achieved through a system of complete perfectly competitive markets. By themselves, these results have very limited implications for policy -- firstly because they apply to an unattainable ideal capitalist system and secondly even within this restricted context they are subject to a number of important caveats of which the DSM (Debreu, Sonnenschein \& Mantel) theorem is probably the most important. ${ }^{11}$

Neo-liberal ideology therefore seeks its intellectual basis in the third welfare theorem which seems to be a recent addition (see Hammond (1993)) to neo-classical welfare economics. This theorem, unlike its predecessors, is not confined to the ideal capitalist system (of complete and perfectly competitive markets), but could apply to virtually any variety of capitalism. The theorem itself asserts that it is possible to reform the original economic system by moving in the direction of complete and perfect markets and in the process generate an equilibrium allocation that is Pareto superior to the original allocation.

The crucial caveats to this theorem are four-fold :

(i) Such Pareto improvements cannot be guaranteed unless those directly harmed by liberalization are suitably compensated by a lump sum redistributive system

(ii) The reforms are to be in the nature of taking the existing system in the direction of the ideal capitalist system.

(iii) The results have pure static validity and their dynamic justification is far from clear

(iv) Natural /environmental resource constraints are completely side-stepped in this model. 
The neo-classical emphasis on free markets ignores one crucial dimension of modern capitalism viz. the emergence of multi-nationals, mega corporations and financial conglomerates. The invisible hand was intended to explain the working of competitive forces in an economy where market power was evenly, if not equally distributed. This basic premise is seriously jeopardized by the overwhelming countervailing power enjoyed by such mega-corporations in modern market economies. Indeed, as Lindblom (1977) has observed "It is possible that the rise of the corporation has offset or more than offset the decline of class as an instrument of indoctrination....That it creates a new core of wealth and power for a newly constructed upper class .. is also reasonably clear. The executive of the large corporation is, on many counts, the contemporary counterpart to the landed gentry of an earlier era, his voice amplified by the technology of modern communication... The major institutional barrier to fuller democracy may therefore be the autonomy of the private corporation." Once the reality of mega-corporations is incorporated into theoretical models of laissez faire or democracy, then some of the neat conclusions deriving from these models are no longer sustainable.

The neo-liberal ideology has cavalierly ignored these caveats and correspondingly, none of the reforming governments in the Third World have paid serious attention to the policy implications of these caveats in actual reform strategies. Talks about level playing fields and social safety nets have remained purely at the rhetorical plane and the capitalist systems which have resulted from reforms have been less oriented towards the establishment of competitive markets than towards the domination of markets by corporate oligarchies and financial agglomerates. In fact in several cases all that reforms have achieved is the replacement of public sector monopolies by private sector monopolies and oligarchies (usually involving TNCs) (see Rodrik \& Subramanian (2004) and Kohli (2006))

Our discussion should make it quite clear that the presumed theoretical case for marketoriented internal and external economic reforms is extremely weak and whether moves in the direction of some form of capitalist system will promote economic growth (and social welfare in general ) or otherwise, becomes essentially an empirical issue. 


\section{MATERIAL PROSPERITY, SOCIAL WELFARE \& DEMOCRACY}

In examining the indirect link between capitalism and democracy, the second important causal chain is from material development to democracy.

The issue of whether increased material prosperity (and general economic development) strengthens the democratic attitudes of the populace may seem to have a straightforward affirmative answer. Indeed Aristotle (1962, [330 B.C.]) had argued that only a wealthy society provided the opportunity for intelligent participation in public affairs, to a majority of its citizens. It is difficult to disagree with Lipset's (1959) observation that " A society divided between a large impoverished mass and a small favoured elite would result either in oligarchy (dictatorial rule of the small upper stratum) or in tyranny (popularly based dictatorship)"

But while a minimal level of development might be necessary for the existence of democracy, the question of whether material development beyond the sustenance level sets in motion forces favouring democracy is a far more complex question. In an important recent book, Benjamin Friedman (2005) has adduced historical evidence to the effect that improved living standards bring about positive changes in social values and raise the standard of political institutions. He also makes the fine distinction that it is the growth, rather than levels, of living standards that are critical for democratic aspirations, cautioning that even wealthy societies, faced with long economic stagnation episodes, could potentially engender values inimical to democratic norms.

Similar views have been advanced by Przeworski \& Limongi (1995), Rueschemeyer et al (1992) and Lipset (1994). In general, these explanations predicate that economic growth brings in its wake greater equality of distribution, better communication, literacy and education. In Lipset's words “ ... the rise of capitalism, a large middle class, an organized working class, increased wealth and education are associated with secularism and the institutions of civil society, ... which facilitate other preconditions for democracy" (Lipset, 1994, p.7) 
Friedman's position is close in spirit to the views of classical thinkers such as Condorcet, Montesquieu and Adam Smith, who stressed "the civilizing effects of commerce" (Hirschman (1986)). Several political theorists, spanning a spectrum of ideologies from Marx to John Stuart Mill, have viewed capitalist development as leading to crass materialism, corrosion of morality and an undermining of individual liberty. As is well known, Marx (1932, original publication 1872) saw economic development and industrialization as culminating in a "dictatorship of the proletariat" whereas Weber (1922 tr. by Henderson \& Parsons 1947) viewed it as likely to lead to a "dictatorship of a bureaucracy". Mill (1963, originally published 1848) warned against the excesses of the market, and while not completely discarding the capitalist order, vehemently argued for important reforms in the system, such as limitations on inheritance, the provision of higher quality education for all, and several other features of a welfare state socialism.

Coming to modern theorists, in his celebrated work, Moore (1966) argued that successful modernization and transformation of agriculture via capitalist modes of production was associated with the emergence of democracies in Britain, France and the United States in the nineteenth century (see also Stephen (1994)) ${ }^{12}$.

An important group of analysts has tried to explore whether the relationship between development and democracy depends on the stage, timing or path of development. Hirschman (1986) for example, seems to suggest that the early stages of development seem to be supportive of democratic values, whereas the connection could become less pronounced or even perverse in the later stages of development (see also Almond (1991)).

The issue of whether the timing of development is an important determinant of political democracy has also attracted a great deal of attention. Two contending hypotheses have been advanced. Firstly, there is the hypothesis due to de Schweinitz (1964) and Moore (1966) that the social, economic and political conditions that existed for the early developers were far more conducive to democracy than those confronting the late 
developers, so that the earlier a country embarks on a development path, the higher its level of political democracy. As the direct antithesis of this hypothesis, Bendix (1976), Collier (1975) etc. argue that late developers face stronger pressures towards adopting democratic ideals, because of cultural transmission of democratic ideas from the already developed democracies through the medium of books, TV, education etc. Bollen (1979) tried to examine both the hypotheses empirically from a cross country panel study, but found little empirical support for either. This, however, is an issue on which further empirical work is certainly called for.

The strategy of development and the implied growth path could also be important considerations in the political outcome. Roemer (1995) develops a formal model, in which the crucial impetus for political transformation comes from important changes in citizen preferences, especially as regards civil liberties. His general conclusion is that political outcomes (or more specifically the emergence of democratic attitudes) is path dependent. Some paths (such as increasing capital stock, increasing labour productivity or decreased inequality of wealth) lead to a perverse relationship between development and democratic attitudes. His explanation is that those development paths which decrease the costs associated with political uncertainty are the ones likely to foster democracy. Path dependence also arises from two other important parameters of the growth process viz. unemployment and inequality. The chronically unemployed (in the working group age) with typically low self-respect, have little likelihood of exercising their civil rights in a responsible manner. If growth aggravates chronic unemployment, then, even if it makes a strong dent on poverty, the overall impact on social welfare is questionable. Similarly if growth is accompanied by greater inequality, this may lead to the emergence of favoured elite groups, which often try to perpetuate their stake in the system through political lobbying, party donations and other stratagems, which ultimately result in emasculating the democratic process.

We have tried to show that the relationship between capitalism and democracy is far more nuanced than usually supposed. Both the direct and the indirect causal chains postulated from capitalism to democracy are extremely tenuous and subject to an 
overwhelming list of qualifications, many of which are extremely unlikely to be fulfilled in practice. In particular, it may be precarious to speculate on the relationship on the basis of over-simplified econometric models, based on questionable data, which seem to be the flavour of many of the studies undertaken in this area. Country studies paying indepth attention to institutional details might be a more promising line of inquiry. It is in this spirit that we now turn our attention to the Indian case.

\section{INDIAN DEMOCRACY : SOME GENERAL FEATURES}

The Indian democratic experience has been watched the world over with great interest, as in several senses it represents a unique constellation of features. The vast literature on the subject, however, presents conflicting perspectives on issues such as democracy and governance, ethnicity, social violence, federal structure, party politics etc. (e.g. Brass (1990), Kohli (1990), Van der Veer (1994), Weiner (1989), Chadda (2000) etc.). While admiration has been frequently expressed for the resilience exhibited by Indian democracy in confronting various challenges, there is also a concern among several analysts that the Indian state partakes of quasi-authoritarianism and Indian democracy, at best, may be regarded as a low quality democracy.

Two broad approaches towards understanding the level of political development in a country may be distinguished viz. the structuralist school and the elite bargaining school.

The structuralist school ( Gasiorowski (1995), Gunther et al (1995) etc.) regards certain structural features in a society as the key to understanding democratic transformations in a society ( the discussion on social prerequisites of democracy in Section II.2 is thus squarely located in this tradition). Most structuralists tend to view democracy in South Asia (not excluding India) in somewhat negative terms. India, Pakistan, Nepal and Sri Lanka all exhibit various degrees of ethnic, caste, religious and regional unrest, which is often curbed by the use of state violence. Both, the manifestations of this kind of unrest and the means of resolving it, lower the democratic worth of these countries in the 
structuralist assessment. However, such a perception may be faulted as resting on a narrow view of democracy, limited to the European democratic transformation. It fails to take into account the important issue of "timing of development" (Bollen (1983)). In Europe the three processes of territorial consolidation, industrialization and democratization, were separated by extended periods of time. By contrast, the South Asian countries have had to cope with all three processes concurrently (Chadda (2000)). Some of the unrest springs from the tensions of industrialization (with hitherto economically and socially disadvantaged groups becoming progressively more assertive about their rights), and a large part of the state violence arises owing to the anxiety of governments operating in a context of incomplete territorial consolidation. Thus the application of strictly European standards to adjudge South Asian democracy is inappropriate and could miss the democratic potential in several of these countries.

Dissatisfaction with the structuralist school has made several scholars turn to the second group of political theories viz. those based on strategic choice or elite bargaining (Diamond (1990), Linz \& Stepan (1997), Przeworski (1992) etc.). These theories focus on fulfilment of certain procedural conditions for democracy, arising out of a process of bargaining among different elite constituents of a society, about power-sharing norms. ${ }^{13}$ Among the major procedures emphasized are :

(i) rule of law

(ii) regular and fair elections

(iii) stability and governance

(iv) a free press and

(v) democratic participation.

These procedures are in a state of continuous evolution and the process of marketization, by shifting the balance of countervailing power between the elite constituents, is likely to affect these conditions in important ways. Apart however from these procedures, one should also focus on the socio-economic outcomes of democracy of which the three most important are : 
(i) growth, poverty and inequality

(ii) environment and natural resources

(iii) corruption (both by state officials and private agents).

We begin by reviewing how a shift to markets has affected the above three outcomes and then turn to the more general issue of how well India measures up to some of the procedural criteria set up by the elite bargaining school as hallmarks of a democracy.

\section{OUTCOMES OF DEMOCRACY IN INDIA}

\section{VIII.1 : GROWTH, POVERTY \& INEQUALITY :}

Poverty reduction is now enshrined as a prime goal of development policy worldwide, and the welfare enhancing effects of economic growth are seen as directly commensurate with the associated reduction in poverty levels. There is by now, a fair degree of unanimity among economists that growth is essential for poverty reduction ${ }^{14}$, under the assumption that the distribution of income remains constant (Deininger \& Squire (1996), Dollar \& Kraay (2002) etc.). However, as shown by Ravallion (2004) (also Bourguinon (2003)) rapid poverty reduction will be hard to achieve, even in the face of high growth rates, if initial income inequality is substantial, or if the growth process itself aggravates inequality. Thus the main leg in the "poverty-growth-inequality triangle" (a concept due to Bourguinon (2004)) is that connecting growth and inequality. Thus the much touted "trickle down" effect of growth policies cannot really be operative unless the inequality dimension is attended to. ${ }^{15}$

We now turn to the Indian situation and examine whether the post-reforms high growth phase has been accompanied by impressive poverty alleviation. The first issue that we need to confront here is that related to poverty measurement. This is a complex issue, and up-to-date estimates on reliable poverty measures are rarely available. International comparisons of poverty levels are fraught with even more serious problems. The standard concept of poverty is the percent of population below a threshold (poverty line), usually based on a minimum level of nutrition in a benchmark year with allowance for some nonfood expenditure and deflated by an appropriate cost of living index. Poverty estimates in India are based on the consumer expenditure surveys carried out by the NSSO (National Sample Survey Organization) ${ }^{16}$. After the reforms three quinquennial surveys have been carried out viz. the $50^{\text {th }}$ NSS Round (1993-1994), $55^{\text {th }}$ NSS round $(1999-2000)$ and $61^{\text {st }}$ NSS Round (2004-2005). As a benchmark pre-reform comparison point, we use the results from the $43^{\text {rd }}$ NSS Round (1987-1988). Results are presented in Table $1^{17}$.

The table brings out starkly the fact that the dent on poverty is nowhere comparable in the post-reforms period to what reforms enthusiasts were prone to claim earlier. Instead of 
declining by nearly $10 \%$ over a 6 year span, it has actually declined only by $8 \%$ over an 11 year span. Thus the average annual decline in the poverty ratio is a meager $0.7 \%$, and not $1.6 \%$ as thought before. ${ }^{18}$ Considering that the rate of population growth in the last decade has been around $1.8 \%$, the decline in the poverty ratio translates into an annual addition to the absolute number of the chronically poor by about $0.2 \%$ (roughly 2 million people over the post-reforms period). The situation appears even more gloomy if one goes by the latest estimates of poverty compiled afresh by the Tendulkar Committee (2009), based on a long-overdue rationalization of the consumption basket of households and a focus on the expenditures relating to capabilities of individuals. The new estimates of poverty are $37.2 \%$ for all of India (with $41.8 \%$ for rural areas and $25.7 \%$ for urban areas). ${ }^{19}$ Chen \& Ravallion(2004) in their well-known comparative study on world poverty, using the international poverty line definition ( $\$ 1.08$ a day per person at 1993 PPP), obtain significantly higher estimates for the HCR (head count ratio) for India than shown in Table 1(for the year 2001 for example their HCR is 34.7\%). Poverty in India has been consistently higher than that in South Asia generally, whether measured by the HCR or by Poverty Gap Indices ${ }^{20}$.

Juxtaposed with the issue of poverty is that of unemployment. Possibly, unemployment is ultimately likely to prove the Achilles' heel of the Indian reforms process. It is now unequivocally accepted that the move to market friendly policies globally, has reduced the employment elasticity of growth (\% increase in employment for a $1 \%$ increase in growth rate), in LDCs, in ex-socialist countries as well as the OECD group of countries. Even in China spectacular growth has co-existed with an urban unemployment problem. The aggravation of the unemployment problem occurs through several channels, the main ones for the LDCs being the following:

1) A decline in the terms of trade (ratio of export prices to import prices) owing to the low level of demand for LDC exports in the advanced countries.

2) Corporate restructuring and mergers $\&$ acquisitions.

3) Rapid growth of labour-saving technologies, mainly introduced into LDCs by multinationals.

4) The global spread of new technologies has brought in its wake a new underclass of "the learning-disabled" consisting of the least educated older workers.

Empirical analysis of unemployment in India is beset both by data problems as well as a multiplicity of measurement concepts. At least four concepts are currently in use viz. UPS (usual principal status), UPSS (usual principal and subsidiary status), CWS (current weekly status) and CDS (current daily status) ${ }^{21}$. The unemployment rates (unemployed as a fraction of the workforce) are presented in Table 2 below, whereas employment growth rates of select sectors is presented in Table 3 (with a breakdown between the organized and unorganized sectors).

Both tables underscore the failure of the Indian reforms process to tackle the unemployment issue with any success. The unemployment rate (all-India) shows an appreciable decline over the pre-reform period (1983 to 1993-1994), but then rises again very sharply over the post-reforms period (1993-1994 to 1999-2000). The conclusion 
applies with similar force to the rural unemployment rates, and also (but with considerably less force) in the urban case. The sectoral story mirrors the broad pattern exhibited by the aggregate unemployment rates. Employment growth ( in both the organized and unorganized sectors) has decelerated sharply in the aftermath of reforms. As in the decade prior to reforms, the unorganized sector continues to grow faster than the organized sector in the post-reforms period ${ }^{22}$. This growth has been accompanied by an increasing casualization of labour (see Deshpande \& Deshpande (2001)).

From a futuristic perspective what is a dangerous portent is the declining employment elasticity of growth across sectors. This is evident from Table 4 , which shows a steep fall in the employment elasticity in the post-reforms period in all sectors except transport, storage \& communications, and finance, insurance, real estate \& business services. In the remaining sectors (accounting for nearly 94\% of the total employment ) employment elasticities have registered moderate to steep declines. If the overall employment elasticity of 0.13 (obtained over the period 1993-1994 to 1999-2000) is taken as obtaining in the near future then even an $8 \%$ rate of growth will increase employment by a mere $1 \%{ }^{23}$.

Inequality is possibly one of the most neglected and least emphasized dimensions of the liberalization programme in LDCs. It becomes a crucial factor determining long-term sustainability of the reforms programme, because of at least two major reasons :

(i) Firstly, the impact of growth on poverty alleviation is critically dependent on the level of initial inequality in a society.

(ii) Secondly, high levels of inequality are inhibitive of the development and survival of democratic norms in a society. Inequality undermines good public policy, by eroding collective decision making processes and social institutions critical to a healthy functioning of democracy (the so-called "vanishing middle class" syndrome as discussed in Nancy Birdsall (2005)).

In a large federal set-up such as India's, inequality has really two major dimensions viz. regional inequality between states and interpersonal inequality. The study by Ahluwalia (2002) (covering 14 major states) showed a sharp increase in the Gini coefficient from 0.175 (1991-92) to 0.233 (1998-99), based on the SDP (state domestic product) per capita $^{24}$. Deaton \& Dreze (2002) reiterate similar conclusions but based on per capita consumption across states. Thus the process of economic reforms in India does seem to have had a noticeably adverse impact on regional inequality. This has the potential to create political tensions in a society where regional loyalties have traditionally been powerful.

Emerging interpersonal inequality in the wake of reforms in the Third world has attracted a great deal of attention from policymakers and academics alike. Several explanations have been advanced for the disequalizing impact of liberalization and globalization : 
(i) So far as trade liberalization is concerned, the so-called Wood thesis (based on standard factor price equalization assumptions) leads us to expect a narrowing of wage differentials in LDCs (see Wood, 1994), a conclusion hardly borne out by the empirical data available. One plausible resolution of this paradox revolves around the inappropriate choice of technologies in LDCs. The import of First World technologies in LDCs often leads to a scarcity rent for skilled labour, aggravating wage inequality (see Lindert and Williamson (2001)). Rodrik (1997) stresses an alternative line of explanation in terms of the political economy of distribution, in a world of mobile capital and immigration inflexibilities.

(ii) In assessing the distributive impact of globalization on LDCs, a key factor is not usually accounted for. This refers to the domestic policy changes (including labour market reforms, tax reforms and privatization) which have to be initiated to render the country an appealing destination for foreign investors. Labour market reforms typically involve relaxation of safety norms, reducing job security, and weakening of collective bargaining mechanisms. These have obvious impacts on wage dispersion. Tax reforms have been characterized by a rolling down of corporation taxes and taxes on trade, with a corresponding rise in indirect taxes. This has been accompanied by a reduction in the progressivity of direct taxes, especially at the top end. This has had some adverse impact on inequality. Privatization and disinvestment, wherever it has occurred on a significant scale, has often led to rapid concentration of national assets in the hands of a small elite, high service charges by the privatized utilities, employment restructuring and erosion of regulatory control. Such a combination of factors has considerable potential for an unfavourable distributional impact.

(iii) Domestic financial sector reform tends to raise the share of financial services in the GDP. A particularly puzzling feature, for which there seems to be no analytical explanation is the relative rise in financial sector salaries as compared to salaries in the manufacturing sector (even after correcting for standard conditioning factors such as education levels, hours worked, nonsalary incentives, etc.). Another factor contributing to inequality is the redistributive impact of the budget which in a largely deregulated financial environment could transfer labour incomes to holders of state bonds.

(iv) The liberalization of cross-border direct investment flows, as well as bank loans and portfolio investments has three potential consequences for inequality. Firstly, there is the "disciplining" effect on domestic policy, involving tax reforms and restraints on organized labour which have already been discussed above. Secondly, capital inflows are likely to lead to real exchange rate appreciation, which shifts resources to the non-tradeables sector and encourages sub-contracting and wage cuts in the tradeables sector to preserve profit margins (see Taylor (2000)). Thirdly, increasing openness of the capital account increases the vulnerability of the domestic economy to financial crises (Caprio \& Klingebiel (1996)). These crises have pronounced disequalizing effects, especially in countries with weak institutions and social safety mechanisms ${ }^{25}$. 
For India, data on interpersonal inequality is extremely scanty. However, in spite of this obvious limitation, a few empirical exercises have been attempted. The central features from empirical studies such as Mundle \& Tulasidhar (1998), Ravallion and Datt (1999) and Jha (2000) are that in the 1990s there has been a moderate rise in both rural and urban inequality (in contrast to the two previous decades when inequality remained constant), accompanied by a decline in urban poverty, but the widening of the rural-urban income gap has implied a significant increase in overall inequality.

\section{2 GROWTH, ENVIRONMENT \& NATURAL RESOURCES :}

Environmental policy is plagued by two interacting market failures, relating to environmental depletion and environmental technology (Jaffe et al (2004)). The invisible hand, of itself, often fails to fully internalize pollution externalities and hence, pollution levels exceed the social optimum, in the absence of state intervention (either in the form of taxes or direct control of emissions via enforcement of environmental standards). In a representative democracy, where governments lean heavily on industry support, the level of taxation on pollution or enforcement of environmental standards will most likely fall short of bridging the wedge between private and social marginal costs. Similar problems beset the use of natural resources. Market prices will rarely reflect the true (shadow cost ) of natural resources, and governments will be reluctant to enforce such prices (and may even subsidize the use of natural resources for populist reasons) so that there is likely to be an accelerated rate of resource depletion.

Environmental technology, by altering the trade-off between the marginal social cost of pollution control and its marginal social benefit, has the potential to reduce overall environmental pollution. However, as is well known, technology partakes of the nature of a public good, and is subject to "knowledge" and "adoption" externalities (Mankiw \& Whinston (1986), Griliches (1992), Goulder \& Schneider (1999) etc.). Additionally incomplete information, compounds the problems of market failure. Hence innovation and diffusion of ECT (environmentally clean technology) is likely to be very tardy, especially in LDCs..

Environment is an issue, which has received relatively little attention in India as yet. Most of the environmental issues are carried forward by a few NGOs amidst general apathy and policy indifference. A part of the on-going environmental degradation may perhaps reflect the so-called environmental Kuznets curve, which postulates an inverted $\mathrm{U}$ relationship between pollution and economic development. ${ }^{26}$ The environmental Kuznets curve is also helpful in understanding the widespread shifting of pollution creating industries from the developed countries (who would be most likely on the downward arc of the inverted U-curve) to LDCs (which usually find themselves on the upward arc). India furnishes a typical example. Ray \& Chaudhury (2004) have identified 17 major dirty industries in India ${ }^{27}$, which between themselves account for about $13 \%$ of the total industrial units in the country and for about $5.65 \%$ of national income. 
On the natural resources front, the situation is to say the least alarming. We illustrate the looming crisis in this vital dimension of long-term social welfare, by a single but vital issue viz. water. As per international norms (see Report of National Water Commission (2002) ) a country is deemed water-stressed if annual per capita water availability falls below $1700 \mathrm{~m}^{3}$ and water-scarce if this availability goes below $1000 \mathrm{~m}^{3}$. In India, the latter threshold was breached in 1991, when annual per capita availability fell to $816 \mathrm{~m}^{3}$. Since then the availability has been declining precipitously, falling to $672 \mathrm{~m}^{3}$ in 2001 , and projected to fall to $495 \mathrm{~m}^{3}$ by 2025 . What makes the situation a frightening one to contemplate is that access to water is extremely unequal, so that the per capita figure is hardly reflective of the privations experienced by innumerable underprivileged households across vast tracts of the country. Urgent measures to overcome this situation are needed (see Kumar et al (2005)), but would need a sharp reorientation in the priorities of the present government. Similar comments apply to several other non-renewable natural resources such as forests, fossil fuels, bio-diversity etc.

\section{VIII.3 CORRUPTION :}

The issue of corruption, though a key constituent of discussions on development, has suffered from a dearth of systematic analysis based on reliable data. Policy initiatives to tackle the issue have also correspondingly been slow and ad hoc. Globalization has meant that the issue of corruption can only be resolved through sustained international cooperation, and here, once again, the very nature of the enterprise has impeded progress. $^{28}$

Strong institutions (judiciary, bureaucracy, police, market regulators, education, public opinion etc) are generally regarded as the most important factor in keeping corruption in check. It is interesting that one of the major planks used by the advocates of reforms to support their case, was that free markets would alleviate corruption in the Third World. This thesis was based on the so-called rent-seeking hypothesis of Tullock (1967), Krueger (1974) and Posner (1975), which proceeds within a strictly neo-classical framework. But as has been extensively noted by later researchers, such a view is unduly restricted, and as a matter of fact, free markets in the absence of strong institutions could aggravate rather than mitigate corruption (Glynn et al (1997), Williams and Beare (1999), Sindzingre (2005) etc.) . In an important recent book, Johnston (2005) presents a much more comprehensive analysis of corruption in LDCs, in which the following taxonomy of Third World corruption is presented : 
1. Influence Market Corruption, which involves efforts on the part of private interests to gain control of policy processes, using the politicians and bureaucrats as middle-men.

2. Elite Cartel Corruption, encompasses a network of political, business, military and ethnic elites, aimed at preserving their hegemony in a largely poor and illiterate society.

3. Oligarch and Clan Corruption, corresponds to a corruption nexus revolving around a handful of government or military officials and entrepreneurs, whose power derives from personal resources.

4. Official Moghuls typically characterize several African or Latin American dictatorships, wherein officials brazenly plunder society for personal gain.

Of course, nobody is denying that that the origins of corruption in India are historical, dating well back to pre-British times. But confining ourselves to the modern period, corruption issues first started coming to wide public attention in the 1970s. This was attributed by a wide section of contemporary commentators to the license-permit Raj then prevailing. As a matter of fact, the rent-seeking hypothesis seemed to serve as a convincing explanation of this type of corruption. One of the major arguments in favour of reforms, espoused by early proponents was that reforms would make a serious dent into corruption, if not eliminate it altogether. In retrospect, however, this claim turned out to be remarkably naïve. Corruption did not recede with the scaling down of controls, but resurged with redoubled vigour. The primary reason for this seems to have been overlooked in the literature viz. that the character of corruption was metamorphosed in the transition to a liberalized economy. The older rent seeking type of corruption has given way to newer forms. Johnston's (2005) analysis above, seems much more germane to the current situation in India. In particular, the first two types of corruption (viz. influence market and elite cartel) that he mentions seem to be the dominant modes in India, though the other two types could perhaps prevail in remote parts of the country, in a strictly localized fashion. The emergence of the newer types of corruption in a liberalized - globalized environment can be explained by the emergence of several mutually reinforcing tendencies, chief among which seem to be the following 
(i) a pronounced rise in the affluence of sections of the population,

(ii) a rise in the wealth aspirations of the general populace

(iii) a comparative retreat of the State from public life, with a corresponding erosion of the social respect and awe with which State power is usually regarded in traditional societies,

(iv) a serious imbalance between official and private sector salaries, resulting in the former facing a steep decline in their relative living standards, in spite of their educational attainments and social status being comparable with their counterparts in the private sector,

(v) the proliferation of newer financial institutions and instruments whose convoluted operations are known only to select market players, and which are often not understood by either public officials or the press, leave alone the ordinary citizen,

(vi) increased financial returns to corrupt activities, with judicial punishments not increasing commensurately with the scale of the corrupt transactions ${ }^{29}$,

(vii) enlargement of escape avenues for large-scale corrupt activities (through party donations, tampering of evidence, influencing investigating authorities, and even bribing sections of the judiciary) and

(viii) above all, increased social tolerance of corruption as an inevitable component of modern life, with some people even claiming that corruption is a kind of lubricant of economic activity. ${ }^{30}$

While the above discussion may not furnish a complete theory of corruption in a liberalized economy, I believe it captures some of the key ingredients that make corruption even more extensive and deep rooted in a market oriented economy than in a public sector dominated mixed economy. 


\section{PROCEDURAL CONDITIONS FOR DEMOCRACY : THE INDIAN CASE}

\section{IX.1 RULE OF LAW :}

Beginning in the 1970s, there is in evidence in India, a progressive deterioration in the rule of law, with political protection and patronage seeping into vital arms of the state machinery including civil services, police and even the judiciary. There is no escaping the fact that tardy judicial reforms, huge backlogs of civil and criminal cases, and the criminal-politician nexus, have seriously eroded public confidence in the rule of law. As discussed above in the context of corruption (Section VIII.3), marketization was widely anticipated to act as a check on these tendencies. However, while marketization has to some extent emasculated the enormous power wielded by the bureaucracy in the prereforms era, it has given rise to vested corporate interests, which have built up their own extensive networks within various arms of the government, and are often successful in influencing legislation to their advantage in matters bearing on their interests (e.g. FDI in retail and SEZs being two famous recent illustrations ). This lobbying power can often become substantial at the state levels, though by the very nature of the subject, concrete evidence is hard to come by.

\section{IX.2 REGULAR AND FAIR ELECTIONS:}

On the criterion of regular and fair elections, India's record may be regarded as reasonable, though far from perfect, given factors such as the criminal background of several electoral contestants, role of black money in funding elections, and the nexus between industry groups and politicians. There are three factors, however, which seem to offer some room for future optimism. Firstly, there is a greater awareness of civil and political rights among all sections of society (on account of literacy, telecommunications, improved labour mobility etc.). This is reflected in increasing resort to PIL

( public interest litigation) and the RTI (Right to Information Act) in recent years. Secondly, there has been a welcome increase in the vigilance of all sections of the media, the several sting operations and exposes having had the effect of putting the actions of 
politicians, bureaucrats and the police under a public scanner. Thirdly, the Election Commission (EC) in recent years has taken on an increasingly pro-active role, often countermanding elections, whenever sharp practices are detected (see Gill (1998)).

\section{IX.3 STABILITY \& GOVERNANCE :}

One of the reasons cited by political theorists such as Diamond (1990), for regarding Indian democracy with a degree of skepticism, is an unstable state, the instability manifesting itself in frequent change of governments and prevalence of coalitions. However, a distinction needs to be made between instability of governments and the instability of the political system. Chadda's (2000) parallel to the Third and Fourth French Republics (1870-1940 and 1946-1958 respectively) is particularly germane in this context. The frequent collapse of the governments in France during this era has not been viewed by historians as signaling a retreat of French democracy. However, frequent government instability could pave the ground for public demand for stronger and more centralized governments, as happened in France when General de Gaulle was voted in as President in 1959 with vastly enhanced powers and a long tenure of seven years.

Governance problems are more serious and in several parts of the country credibility of government is all but non-existent. This lack of credibility either manifests itself in general lawlessness or occasionally in separatist movements or civil war type of conditions. Insurgency movements (such as those in the Punjab in the 1980s, in the North-East since 1970s and Naxalism in the past few years) coupled with organized crime have rendered vast tracts of land ungovernable (see Ketkar (2003)). Marketization, while hardly the sole causal factor, may be viewed as a secondary aggravating factor behind some of the social unrest such as Naxalism and communal riots, whose origins can be partly traced to the inequality and marginalization associated with the implementation of market reforms in India. ${ }^{31}$ 


\section{IX.4 FREEDOM OF THE PRESS AND MEDIA:}

The Indian press has had a long and respected tradition of integrity, social accountability and pluralism. In the 1970s and 1980s, the Press served as a forum for several intellectual and ideological debates of an exceptionally high order. The leading role of the Press in curbing the excesses of the Emergency and in ultimately bringing about its termination, is now a historically accepted fact. Similarly the IMF loan and the Uruguay Round negotiations of the 1980s, generated rich debates in the Press in which intellectuals participated heartily, irrespective of their ideological colour. In the 1970s and 1980s, the main danger to the freedom of the Press came from an aggressive State-a danger that the Press was largely successful in warding off. But a new and much more subtle threat to Press freedom has emerged in the liberalized regime viz. corporate interests backed by money power, often acting in conjunction with the government. Corporate financial control has long been the dominant mode of Press ownership in India, but this model worked well as long as editorial independence was sanctified. In the wake of liberalization, this healthy "arms' length" relationship between the editorial office and the management was dissipated, and editorial freedom was made subservient to management interests. This has implied a complete overhaul in the style of newspaper functioning in India. News coverage and news analysis has undergone a metamorphosis. The base of the readership has been sought to be widened by sacrificing serious content, in favour of entertainment oriented reportage. Few dailies have been able to withstand the allurements of huge assured advertisement revenues. Simultaneously, there is in evidence a concerted attempt to influence readers in the direction of the new market philosophy. The broad plurality of views and the lively debates, so much a hallmark of the earlier years, seems to have given place to a certain standardisation of expression, and an impression sought to be deliberately created about a societal consensus on liberalization and globalization.

A key role in fostering this "orchestrated consensus", has been assigned to a new breed of editorial collaborators, comprising primarily corporate economists, management gurus, and financial executives who share a common and somewhat naïve optimism 
about the marketization philosophy, regarding every move in the direction of markets and globalization as welfare enhancing, blissfully unaware of the necessary caveats that more careful analysts would enter. It is thus extremely unfortunate that courtesy the media, the terms of economic discourse in India have become the virtual monopoly of this group of contributors, who with their casual empiricism and short-term sectional perspectives often act as a strong pressure group and even as a feedback and grading mechanism for regulators and policymakers, who often are lured into the trap of following the markets by following the market analysts. ${ }^{32}$ Thus policymakers often end up adopting the markets' short-term horizon as their own which lends an unwarranted and dangerous "short-termism" to official policy. In turn, long-term issues like unemployment, regional imbalances, energy, environment, natural resources and demographic change get relegated to the background of national consciousness.

\section{IX.5 DEMOCRATIC PARTICIPATION:}

Public opinion has always been regarded as an essential pillar of a vibrant democracy. Its quality is governed by a host of factors, some historical and others societal, whereas its effectiveness depends directly on the influence that intellectuals are allowed to exert on the decision-making processes of that society. Formal theories of how public opinion shapes the course of democracies may be found in Easterlin (1998), Putnam et al (1993), Avner \& Putterman (1998) etc. but we adopt a more informal mode of analysis here.

One can distinguish at least four major avenues through which intellectual opinion can contribute to national policy in a modern democracy.

(i) Direct participation in the political process

(ii) Serving as advisors and consultants on official and semi-official bodies concerned with policy formulation.

(iii) Serving as public representatives on boards of banks, institutes, companies etc. and 
(iv) Influencing public opinion and acting as its watchdog through books and popular media vehicles, especially newspapers and T.V.

All of these four possible roles have been steadily eroded in India, over the past thirty years or so, till we find today, that the intellectual has been virtually expelled from the national consciousness.

Direct participation of intellectuals in the political process, while a common feature of the Independence struggle, seems to have steadily declined over the years in direct proportion to the increasing role played by money power in the electoral process and the growing nexus between crime and politics. But while the withdrawal of the intellectual from the political arena is possibly in line with trends elsewhere, the gradual eclipse of the advisory role of the intellectuals in policy-making bodies seems to be a specifically South Asian feature. This has not been without an impact on the general quality of these organisations, which have become pale shadows of their former selves. Their autonomy has been seriously eroded. Several of them are today dominated by social scientists (often appointed either at the behest of international multilateral bodies or to appease sectional domestic interests), who predictably end up acting as apologists for policies determined by the political leadership, instead of functioning as independent and disinterested advisers ${ }^{33}$.

The politicization of the top policy-making bodies has in due course filtered downwards. The role of public representatives on boards of banks, companies etc. had traditionally been allotted to distinguished senior professionals, experts or academics. However, over time, political appointees on boards have become a well-established norm. Liberalisation and the growing importance of the corporate sector has in turn, implied a desire by big businesses to exercise control on banks and other financial institutions. The list of board members of several financial institutions (including nationalized banks) appears today like the Who's Who of corporate India ${ }^{34}$.

The above noted features have left intellectuals only one avenue for expressing their involvement with social concerns viz. the popular media comprising primarily newspapers. But as discussed above, the Indian media today is largely dominated by the 
interests of large business, and fully preoccupied in its role as an endorsement of official policy (to the extent that such policy is in consonance with corporate interests).

\section{CONCLUSIONS}

Beginning the middle of the nineteenth century right up to the Second World War, there were two diametrically opposed utopian visions - the capitalist vision in which democracy and capitalism were seen as mutually reinforcing ${ }^{35}$, and its Marxian antithesis that only the elimination of markets and private property could result in the emancipation of the working classes and the establishment of a genuine democracy (Hirschman 1986, Flora \& Heidenheimer 1981, Olson 1982 etc). It is interesting to note that whereas Marxist intellectuals have long abandoned this orthodox Marxist position (Poulantzas 1985, Offe 1984, Gramsci 1971 etc), the laissez faire proponents have, if anything, become even more orthodox in their emphasis on market forces ${ }^{36}$

Apart from the economic efficiency arguments put forth in favour of the laissez faire economy, several prominent thinkers have seen markets as reinforcing the democratic forces in a society. This was viewed as operating through two channels - via a common set of values and attitudes shared by the two systems and an indirect linkage of marketization and democracy via growth, material prosperity and welfare. However we have tried to show that in general, societies may exhibit distinct preferences towards increased material prosperity and democratic institutions, depending on the stage of their development. In particular, material welfare need not always be followed by greater democratic aspirations. Thus the proposition that marketization enhances democracy via a benevolent chain based on growth, social welfare and a shared value system, is fraught with far too many qualifications, to claim general validity.

The second half of our paper is a brief foray into the factors conditioning Indian democracy and how the liberalization process under way since 1990, has impinged these factors. While generalizations are hazardous, they are hard to resist, and possibly the only assessments possible in the absence of detailed empirical data. Bearing these 
qualifications fully in mind, we venture to assert that the process of marketization and globalization in India, as it has proceeded since 1997, may be viewed as guided by a naïve belief in the magic of markets, instead of a strategic move towards reforms (as was largely the case from 1992 to 1997). The pacing and sequencing aspects of liberalization have been virtually ignored, the reforms process being buffeted around by corporate lobbying on the one hand and the aspirations of a growing elite consumerist class on the other. This kind of haphazard marketization is liable to accentuate several of the inherent tensions between marketization and democracy, and in the long run pose threats both to the economy as well as to civil society. Among the potential sources of social malaise, the following seem to be the most important:

(i) the long-term sustainability of a "service-led" growth

(ii) the implications for poverty and unemployment of high growth concentrated in a few leading service sectors, with relative stagnation in traditional manufacturing sectors

(iii) the limits to natural resources such as water and minerals, owing to the absence of any long-term strategies

(iv) the widening gap between advanced and backward states in India

(v) the aggravation of corruption that has resulted from the strongly "probusiness" type of liberalization followed in India

(vi) the increased vulnerability of the economy to financial crises, and the regressive burden imposed by such crises on the poor

(vii) the social and political problems associated with increasing inequality of incomes and growing wage differentials between the skilled and unskilled labour force (both of which are enhanced under market oriented reforms)

(viii) the process of marketization also poses several threats to press freedom, and the expression (and quality) of public opinion.

In his Introduction to the IEA Conference volume on Democracy and Development, Bagchi (1995) has succinctly summed up the complex interactions between democracy and capitalism in the Third World as follows 
"A more principled distinction between the development of individual capabilities .... and the development of the economy may be helpful for clarity. The relevance of texts in discussion of the traditions of democratic and authoritarian strands of political thought must be assessed in the context of whether decent human existence is permitted under the regime being advocated, given the geopolitical setting of particular countries. At the same time social scientists should be aware of selective amnesia in judging the relevance of particular discourses.....the local setting of political discourse and the social relations giving shape to particular economic regimes can be ignored only at the risk of rendering the academic analysis of the linkages between democracy and development irrelevant for most participants in the economic and political process."

In the light of Bagchi's quotation, one can only express the pious hope that Indian policymakers make a sincere effort to understand Indian reality better, before attempting to change it further. 


\section{REFERENCES}

1. Ahluwalia, M.S. (2002) : "State Level Performance Under Economic Reforms In India" in Anne Krueger (Ed) Economic Policy Reforms And The Indian Economy , University of Chicago Press, Chicago

2. Almond, G.A. (1991) : “Capitalism and democracy” Political Science and Politics, vol.24 (3), p.467-474

3. Amable, B. (2003) : The Diversity of Modern Capitalism, Oxford University Press, Oxford, UK:

4. Aristotle (1962) : The Politics, Penguin Press, Baltimore.

5. Avner, B. \& L.Putterman (1998) : "Values and institutions in economic analysis" in B. Avner \& L.Putterman (Ed) Economics, Values and Organizations, Cambridge University Press, New York

6. Bagchi, A.K. (1995) (Ed.) : Democracy and Development : Proceedings of the IEA Conference held in Barcelona, Spain, St. Martin's Press, New York

7. Bartelmus, P. (2008) : Quantitative Neo-Economics : How Sustainable are our Economies?, Dordrecht Springer

8. Baumol, W.J., R.E.Litan and C.J.Schramm (2007) : Good Capitalism, Bad Capitalism and the Economics of Growth and Prosperity, Yale University Press, New Haven

9. Bendix, R. (1976) : "The mandate to rule : An introduction" Social Forces, Vol. 55, p.242-256 
10. Birdsall, N. (2005) “Why Inequality Matters in a Globalizing World” WIDER Annual Lecture

11. Blinder, A.S. (1997) : "What central bankers could learn from academics and vice versa" Journal of Economic Perspectives, vol. 11 (2), p.3-19.

12. Bollen, K.A. (1983) : "World system position, dependency and democracy : The cross-national evidence” American Sociological Review vol. 48 (4), p.468-479

13. Bollen, K.A. (1990) : "Political democracy : Conceptual and measurement traps"

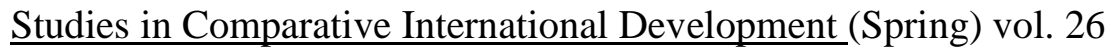

14. Bourguignon, F. (2003) : "The growth elasticity of poverty reduction : Explaining heterogeneity across countries and time periods" in T.Eicher \& S.Turnovsky (ed) Inequality and Growth : Theory and Policy Implications, MIT Press, Cambridge

15. Bourguignon, F. (2004) : "The poverty-growth-inequality triangle" Paper presented at ICRIER Conference (4 February)

16. Brass, P. (1990) : Politics of India since Independence, Cambridge University Press, New York

17. Cammack, P. (1997) : Capitalism and Democracy in the Third World : The Doctrine for Political Development, Leicester University Press, London

18. Caprio, G. and D. Klingebiel (1996) : “ Bank Insolvencies : Cross-Country Experience" World Bank Policy Research WP No.1620, Washington, D.C

19. Chadda, M. (1997) : Ethnicity, Security and Separatism , Columbia University Press, New York 
20. Chadda, M. (2000) : Building Democracy in South Asia , Vistaar Publications, New Delhi

21. Chen, S. and M. Ravallion (2004) : "How Have The World's Poorest Fared Since The Early 1980s ?" Washington, D.C. : Development Research Group, World Bank

22. Chua, A. (1998) : "Markets, democracy and ethnicity : Towards a new paradigm for law and development" The Yale Law Journal, vol. 108, p. 1-107

23. Cohen, C. (1971) : Democracy, University of Georgia Press, Georgia

24. Collier, D. (1975) : "Timing of economic growth and regime characteristics in Latin America" Comparative Politics, vol. 7, p.331-359

25. Dahl, R.A. (1989) : Democracy and Its Critics, Yale University Press, New Haven, CT

26. de Schweinitz, K. (1959) : "Industrialisation, labour controls and democracy", Economic Development and Cultural Change, vol.. 7, p.385-404

27. de Schweinitz, K. (1964) : Industrialisation and Democracy, Free Press, Glencoe

28. Deaton, A. and J. Dreze (2002) : "Poverty and Inequality in India : A Reexamination” Economic and Political Weekly, 7 September p. 3729-3748

29. Debreu, G. (1974) : "Excess demand functions" Journal of Mathematical Economics, vol.1, p.15-23 
30. Deininger, K. \& L.Squire (1996) : "A new data set for measuring income inequality" World Bank Economic Review vol. 10 (3), p.565-591

31. Deshpande, S. and L.K.Deshpande (2001) : "Reforms and Labour Market in India" Paper Presented at National Seminar on Economic Reforms and Employment in the Indian Economy (Institute of Applied Manpower Research, March 22-23)

32. Diamond, L. (1990) : "Three paradoxes of democracy" Journal of Democracy, vol. 3 (Summer), p.48-66

33. Diamond, L. \& M.F.Plattner (ed) (1993) : The Global Resurgence of Democracy, John Hopkins University Press, Baltimore

34. Diwan, I. (2000) : “Labour Shares and Globalization” Paper Presented at a Conference on Poverty and Inequality in Developing Countries, OECD Development Center, Paris

35. Dollar, D. \& A.Kraay (2002) : “Growth is good for the poor” Journal of Economic Growth, vol.7(3), p.195-225

36. Duch, R.M. (1993) : “ Tolerating economic reform : Popular support for transition to a free market in the Former Soviet Union" American Political Science Review, vol. 87 , p.590-608

37. Easterlin, R. (1998) : Growth Triumphant : The Twenty First Century in Historical Perspective, University of Michigan Press, Ann Arbor

38. Finifter, A.W. \& E.Mickiewicz (1992) : "Redefining the political system of the USSR : Mass support for political change" American Political Science Review, vol. 86, p.857-874 
39. Flora, P. and A. Heidenheimer (1981) : The Development of Welfare States in

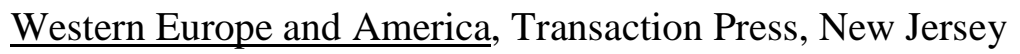

40. Friedman, B. (2005) : The Moral Consequences Of Economic Growth, Alfred Knopf, New York

41. Friedman, M. (1963) : Capitalism And Freedom, Phoenix Books, Chicago

42. Galbraith, J.K. and J. Lu (1999) : "Inequality and Financial Crises : Some Early Findings" UTIP WP. No. 9, LBJ School of Public Affairs, University of Texas at Austin.

43. Gasiorowski, M.J. (1995) : "Economic crisis and political regime change : An event history analysis" American Political Science Review, vol.89 (4), p. 882-897

44. Gill,M.S. (1998) : “India : Running the world's biggest elections” Journal of Democracy, vol. 9(1)

45. Glynn, P., S. Kobrin and M.Naim (1997) : “ The globalization of corruption” in Elliott, K. (ed) Corruption and the Global Economy, Institute for International Economics, Washington

46. Goulder, L.H. \& S.H.Schneider (1999) : "Induced technological change and the attractiveness of $\mathrm{CO} 2$ emissions abatement" Resource and Energy Economics, vol.21, p.211-253

47. Gramsci, A. (1971) : Selections from the Prison Notebooks, International Publishers, Berlin 
48. Griliches, Z. (1992) : “The search for R\&D spillovers” Scandinavian Journal of Economics, vol. 94, S29-S47

49. Gunther, R., P.N.Diamandourous \& H.J.Puhle (ed) (1995) : The Politics of Democratic Consolidation: Southern Europe in Comparative Perspective, John Hopkins University Press, Baltimore

50. Hahn, F. (1975) : "Revival of Political Economy : The Wrong Issues and the Wrong Arguments" Economic Record, Vol. 51, p.360-364

51. Hall, P.A. and D. Soskice (ed.) (2001) : Varieties of Capitalism : The Institutional Foundations of Comparative Advantage , Oxford University Press, New York

52. Hammond, P.J. (1993) : "Efficiency and market failure" in A.P.Kirman (ed) Elements of General Equilibrium Analysis, Basil Blackwell, Oxford.

53. Hansda, S. and P. Ray (2006) : "Employment and Poverty in India during the 1990s : Is there a Diverging Trend?" Economic and Political Weekly, ( 8 July) : 3014-3023

54. Hayek, F.A. (1944) : The Road to Serfdom, Routledge Press, UK

55. Hayek, F.A. (1960) : The Constitution of Liberty, University of Chicago Press.

56. Hirschman, A. (1986) : Rival Views of Market Society, New York, Viking

57. Hodgson, G.M.(1997) : "The Fate of the Cambridge Capital Controversy" in Arestis, P., G. Palma and M.Sawyer (ed). Capital Controversy, Post-Keynesian Economics and the History of Economics : Essays in Honour of Geoff Harcourt, London : Routledge, 
58. Jaffe, A.B., R.G.Newell \& R.N.Stavins (2004) : A Tale of Two Market Failures : Technology and Environment Policy Resources for the Future Discussion Paper \# 04-38

59. Jha, R. (2000) : “ Reducing Poverty and Inequality In India : Has Liberalization Helped?" UNU/WIDER WP No. 204, Helsinki, Finland

60. Johnston, M. (2005) : Syndromes Of Corruption : Wealth, Power And Democracy, Cambridge University Press, UK

61. Kemp, M.C. \& K.Shimomura (2002) : "The Sonnenschein-Debreu-Mantel Proposition and the theory of international trade" Review of International Economics, vol. 10(4), P.671-679

62. Ketkar, P. (2003) : "Organized criminal networks : A challenge to Indian democracy" Peace and Conflict, vol. 6(3)

63. Kohli, A. (1990) : India's Democracy : An Analysis of Changing State-Society $\underline{\text { Relations, }}$ Princeton University Press, Princeton

64. Kohli, A. (1997) : "Can democracies accommodate ethnic nationalism? Rise and decline of self-determination movements in India" Journal of Asian Studies vol. $56(2)$, p. $325-344$

65. Kohli, A. (2006) : "Politics of Economic Growth in India , 1980-2005: I \& II" Economic and Political Weekly, 1st and 8th April

66. Kraay, A. (2005) : "When is growth pro-poor? Evidence from a panel of countries" Journal of Development Economics, vol. 80(1), p.198-227 
67. Krueger, A. (1974) : "The political economy of the rent-seeking society" American Economic Review, vol. 64, 291-303

68. Kumar, R., R.D. Singh and K.D. Sharma (2005) : "Water Resources of India" Current Science, vol. 89 (5), p. 794-811

69. Lijphart, A. (1996) : "The puzzle of Indian democracy : A consociational interpretation" American Political Science Review, vol. 90 (2), p. 258-268

70. Lijphart, A. (1999) : Patterns of Democracy : Government Forms and Performance in Thirty-Six Countries, Yale University Press, New Haven and London

71. Lindblom, C.E. (1977) : Politics and Markets, Basic Books, New York

72. Lindert, P. and J. Williamson (2001) : “Does Globalisation Make The World More Unequal?" Paper Presented at an NBER Conference On Globalisation In Historical Perspective, Santa Barbara, California

73. Linz, J. \& A.Stepan (1997) : Problems of Democratic Transition and Consolidation : Southern Europe, South America and Post-Communist Europe, John Hopkins University Press, Baltimore

74. Lipset, S.M. (1959) : "Some social requisites for democracy : Economic development and political legitimacy" American Political Science Review, vol. $53(1)$, p. $69-105$

75. Lipset, S.M. (1994) : “ The social requisites of democracy revisited" American Sociological Review, vol. 59, p. 1-22 
76. Lopez, J.H. \& L.Serven (2006) : A Normal Relationship ? Poverty, Growth and Inequality, World Bank Policy Research Working Paper \# 3814

77. Mankiw, N.G. \& M.D.Whinston (1986) : "Free entry and social inefficiency" Rand Journal of Economics, vol.17(1), p.48-58

78. Mantel, R. (1974) : "On the characterization of aggregate excess demand" Journal of Economic Theory, vol.7, p.348-353

79. Marx, Karl (1932) : Das Kapital, Verlag fur Literatur und Politik , Berlin (originally published 1872)

80. Marx, Karl (2001) : Critique of the Gotha Programme, Electric Book Co. Ltd., London (originally published 1875)

81. Mill, J.S. (1963): Principles of Political Economy, vol. 2 \&3 of J.M.Robson (ed) Collected Works of John Stuart Mill, University of Toronto Press, Toronto (original publication 1848)

82. Moore, B (1966) : The Social Origins of Dictatorship and Democracy, Beacon Press, Boston.

83. Mundle, S. and V. Tulasidhar (1998) : Adjustment and Distribution: The Indian Experience, Occasional Paper No. 17, Asian Development Bank, The Philippines

84. Neher, C.D. \& R.Marlay (1995) : Democracy and Development in Southeast Asia, Westview Press, Boulder, Colorado

85. OECD(2000). A Report on Business and Industry, Policy Forum, Paris

86. OECD(2003). Convention on Combating Bribery, Policy Forum, Paris 
87. Offe, C. (1984) : Contradictions of the Welfare State, Hutchinson, London

88. Olson, M. (1982) : The Rise and Decline of Nations, Yale University Press, New Haven CT

89. Olson, M. (1991) : "Autocracy, democracy and prosperity” in R.J.Zeckhauser (ed) Strategy and Choice, MIT Press, Cambridge, MA

90. Patnaik, B. (2009) : “The poverty estimates debate” Mint (13 December)

91. Plekhanov, G. (1974) : Socialism and the Political Struggle, Progress Publishers, Moscow, (originally published 1883)

92. Posner, R.A. (1975) : "The social costs of monopoly and regulation" Journal of Political Economy, vol. 83, p.807-827

93. Poulantzas, N. (1985) : Marxist Theory and Political Strategy, Macmillan, London

94. Przeworski, A (1992) : "The neoliberal fallacy" Journal of Democracy, vol. 3, No.3, p.45-59

95. Przeworski, A. and F. Limongi (1995) : "Political regimes and economic growth" in A. Bagchi (ed) Democracy and Development, St. Martin's Press, New York

96. Putnam, R.D. (with R.Leonardi \& R.Y.Nanetti) (1993) : Making Democracy Work : Civic Traditions in Modern Italy, Princeton University Press, Princeton, NJ 
97. Radhakrishna, R. and M. Panda.(2006) "Macroeconomics of Poverty Reduction : Indian Case Study" (Study carried out for the Asia-Pacific Regional Programme on the Macroeconomics of Poverty Reduction), UNDP

98. Ravallion, M. (2004) : Pro-Poor Growth : A Primer, The World Bank, Policy Research Working Paper \# 3242

99. Ravallion, M. and G. Datt (1999) : "When is growth pro-Poor ? Evidence from the diverse experience of Indian States" The World Bank, Washington, D.C. (mimeo)

100. Ravich, S.F. (2000) : Marketization and Democracy : East Asian Experiences, Cambridge University Press, New York

101. Ray, N. and B. Chaudhury (2004) : Understanding Social Choice through PL Factor of Indian Dirty Industries, New Delhi : Ministry of Statistics \& Programme Implementation, Government of India.

102. Reisinger, W.M., A.H.Miller, V.L.Hesli \& K.Maher (1994) : "Political values in Russia, Ukraine and Lithuania : Sources and implications for democracy” British Journal of Political Science, Vol. 45, p. 183-223

103. Rizvi, S.A.T.(1994) : "The Microfoundations Project in General Equilibrium Theory" Cambridge Journal of Economics, Vol. 18, No.4, p. 357-377

104. Rodrick, D. (1997) : Has Globalisation Gone Too Far ? Institute For International Economics, Washington, D.C.

105. Rodrik, D. and A. Subramanian. (2004) "Why India can Grow at 7 Per Cent or More ?" Economic and Political Weekly, (17 April), p. 1591-1596 
106. Roemer, J. (1995) : "On the relationship between economic development and political democracy" in A. Bagchi (ed) Democracy and Development, St. Martin's Press, New York

107. Rostow, W.W. (1971) : Politics and the Stages of Economic Growth, Cambridge University Press, New York

108. Rueschemeyer, D. (1991) : "Different methods, contradictory results : Research on development and democracy" International Journal of Comparative Sociology, vol. 23

109. Rueschemeyer, D., E. Stephens and J. Stephens (1992) : Capitalist Development and Democracy, University of Chicago Press

110. Schumpeter, J.A. (1987) : Capitalism, Socialism And Democracy, Unwin Paperbacks, London, (First Published 1943)

111. Sen, A.K. (2007) : "Democracy and social welfare" in K.Basu (ed) The Oxford Companion to Economics in India, Oxford University Press, New Delhi

112. Sen, Abhijit and Himanshu (2004) : "Poverty and Inequality in India-II: Widening Disparities during the 1990s", Economic and Political Weekly, September 25, p. 4361-4375.

113. Shapiro, I. (1993) : “ The Third Wave : Democratization in the late twentieth century” World Politics, vol.46(1), p.121-150

114. Shiller, R.J., M.Boycko \& V.Korobov (1991) : "Popular attitudes towards free markets : The Soviet Union and the United States compared" American Economic

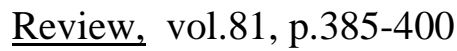


115. Sindzingre, A. (2005) : “ Social networks, states and rents : Contrasting corruption in Africa and Asia" in M.Johnston (ed) Civil Society and Corruption : Mobilizing for Reform, University Press of America, Lanham, MD

116. Sonnenschein, H. (1974) : "Market excess demand functions" Econometrica, vol. 40, p.549-563

117. Stephen, J.D. (1994) : "Capitalist development and democracy : Empirical research on the social origins of democracy" in D.Copp, J.Hampton \& J.Roemer (ed) The Idea of Democracy, Cambridge University Press, New York

118. Taylor, L (2000) : “ External Liberalization, Economic Performance and Distribution in Latin America and Elsewhere" UNU/WIDER WP. No. 215

119. Tullock, G. (1967) : "The welfare costs of tariffs, monopolies and thefts" Western Economic Journal, vol. 5, p.224-232

120. van der Veer (1994) : Religious Nationalism : Hindus and Muslims in India, University of California Press, Berkeley

121. Wald, A.(1936) : Uber Die Produktionsgleichungen der Okonomischen Wertlehre in K.Menger (ed.) Ergebnisse Eines Mathematischen Kolloquims, Vol. 7, p. 1-6

122. Weber, Max (1922) : The Theory of Social and Economic Organization, (Tr. by L.J.Henderson \& T.Parsons 1947) Oxford University Press, New York

123. Weber, Max (1946) : Essays In Sociology, Oxford University Press, New York

124. Weiner, M. (1989) : The Indian Paradox, Sage Publications, New York 
125. Weitzman, M.L. (1993) : "Capitalism and democracy" in Samuel Bowles et al (ed.) Markets and Democracy : Participation, Accountability and Efficiency, Cambridge Univ. Press, Cambridge

126. Williams, J.W. and M.E. Beare (1999) : “ The business of bribery, economic liberalization and the 'problem' of corruption" Crime, Law and Social Change, Vol. 32, p. 115-146

127. Wood, A. (1994) : North-South Trade, Employment and Inequality : Changing Fortunes in a Skill-Driven World, Clarendon Press, Oxford 
TABLE 1

POVERTY MEASUREMENT -HCR (HEAD COUNT RATIO)

\begin{tabular}{|c|c|c|c|c|}
\hline & $1987-1988$ & $1993-1994$ & $1999-2000$ & $2004-2005$ \\
\hline Rural & $39.1 \%$ & $37.3 \%$ & $27.1 \%$ & $22 \%$ \\
\hline Urban & $38.2 \%$ & $32.4 \%$ & $23.6 \%$ & $21.6 \%$ \\
\hline All-India & $38.9 \%$ & $36 \%$ & $26.1 \%$ & $28 \%$ \\
& & & & \\
\hline
\end{tabular}

Source: Sen \& Himanshu (2004) and Radhakrishnan \& Panda (2006)

TABLE 2

\section{UNEMPLOYMENT RATES \% (CDS BASIS)}

\begin{tabular}{|c|c|c|c|}
\hline & $\mathbf{1 9 8 3}$ & $\mathbf{1 9 9 3 - 1 9 9 4}$ & $\mathbf{1 9 9 9 - 2 0 0 0}$ \\
\hline ALL-INDIA & 8.30 & 5.99 & 7.32 \\
\hline RURAL & 7.96 & 5.61 & 7.21 \\
\hline URBAN & 9.64 & 7.19 & 7.65 \\
\hline
\end{tabular}

Source: NSSO Various Rounds 
TABLE 3

SECTOR-WISE EMPLOYMENT GROWTH RATES $\underline{\text { (CDS BASIS })}$

\begin{tabular}{|c|c|c|c|c|}
\hline & \multicolumn{2}{|c|}{ ORGANIZED } & \multicolumn{2}{|c|}{ UNORGANIZED } \\
\hline SECTOR & 1983-1994 & 1994-2000 & 1983-1994 & $1994-2000$ \\
\hline 1.Agriculture & 0.02 & -1.00 & 2.23 & 0.03 \\
\hline $\begin{array}{l}\text { 2. Mining \& } \\
\text { Quarrying }\end{array}$ & -1.91 & -1.30 & 3.68 & -2.40 \\
\hline 3.Manufacturing & 2.58 & 0.87 & 2.26 & 2.95 \\
\hline $\begin{array}{l}\text { 4. Electricity, } \\
\text { Gas \& Water } \\
\text { Supply }\end{array}$ & -3.55 & 0.51 & 5.31 & -17.00 \\
\hline 5. Construction & 5.21 & -0.69 & 4.18 & 5.85 \\
\hline $\begin{array}{l}\text { 6. Trade, Hotels } \\
\& \text { Restaurants }\end{array}$ & 5.72 & 1.43 & 3.80 & 5.79 \\
\hline $\begin{array}{l}\text { 7. Transport, } \\
\text { Storage \& } \\
\text { Communications }\end{array}$ & 5.53 & 0.21 & 3.35 & 7.59 \\
\hline $\begin{array}{l}\text { 8. Finance, } \\
\text { Insurance, Real } \\
\text { Estate \& } \\
\text { Business } \\
\text { Services }\end{array}$ & 5.40 & 1.27 & 4.60 & 8.30 \\
\hline $\begin{array}{l}\text { 9. Community, } \\
\text { Social \& } \\
\text { Personal } \\
\text { Services }\end{array}$ & -2.08 & 0.8 & 3.85 & -3.56 \\
\hline All Sectors & 1.07 & 0.56 & 2.67 & 1.12 \\
\hline
\end{tabular}

Source: Planning Commission (2002), Hansda \& Ray (2006). 
TABLE 4

SECTOR-WISE EMPLOYMENT ELASTICITIES (CDS)

\begin{tabular}{|c|c|c|c|}
\hline SECTOR & $\begin{array}{c}\text { SHARE OF } \\
\text { EMPLOYMENT } \\
(1999-2000) \\
(\%)\end{array}$ & $\begin{array}{c}\text { PRE-REFOPRM } \\
\text { PERIOD } \\
\text { 1983-1984 TO } \\
1993-1994\end{array}$ & $\begin{array}{c}\text { POST-REFORM } \\
\text { PERIOD } \\
\text { 1993-1994 TO } \\
\text { 1999-2000 }\end{array}$ \\
\hline 1.Agriculture & 56.7 & 0.48 & 0.01 \\
\hline $\begin{array}{l}\text { 2. Mining \& } \\
\text { Quarrying }\end{array}$ & 0.67 & 0.61 & -0.49 \\
\hline 3. Manufacturing & 12.11 & 0.32 & 0.20 \\
\hline $\begin{array}{l}\text { 4. Electricity, Gas \& } \\
\text { Water Supply }\end{array}$ & 0.34 & 0.48 & -0.52 \\
\hline 5. Construction & 4.44 & 1.27 & 1.00 \\
\hline $\begin{array}{l}\text { 6. Trade, Hotels \& } \\
\text { Restaurants }\end{array}$ & 11.15 & 0.67 & 0.38 \\
\hline $\begin{array}{l}\text { 7. Transport, } \\
\text { Storage \& } \\
\text { Communications }\end{array}$ & 4.05 & 0.55 & 0.56 \\
\hline $\begin{array}{l}\text { 8. Finance, } \\
\text { Insurance, Real } \\
\text { Estate \& Business } \\
\text { Services }\end{array}$ & 1.38 & 0.49 & 0.68 \\
\hline $\begin{array}{l}9 . \\
\text { Community,Social } \\
\& \text { Personal Services }\end{array}$ & 9.16 & 0.63 & 0.02 \\
\hline All Sectors & 100 & 0.36 & 0.13 \\
\hline
\end{tabular}

Source: Planning Commission (2002) 


\title{
ENDNOTES
}

\begin{abstract}
${ }^{1}$ Of course, the above consensus is not universal, and large sections of populations (as well as the intelligentsia) in mainly the underdeveloped countries remain unconvinced by the elegantly argued out logic of its proponents. Not surprisingly therefore, market based policies have often met with substantial popular resistance. The process by which Third World governments have been able to overcome opposition to such policies and whether in the process, certain democratic principles have been compromised, is an issue to which insufficient attention seems to have been devoted. We propose therefore in our paper to devote some attention to this issue too.
\end{abstract}

${ }^{2}$ This is of course, not to deny the existence of substantial and influential sections of opinion, which have episodically dominated world politics, and which are in outright opposition to democratic ideals. Fascism (as expounded by philosophers such as Fichte and Gentile) on the one hand, and communism drawing inspiration from thinkers such as Marx (2001, originally published 1875) and Plekhanov (1974, originally published 1883), on the other.

${ }^{3}$ Needless to say, the various issues listed, are so strongly inter-connected, that presenting them in a compartmentalized fashion would not only be highly artificial, but might also conceal important synergic and feedback effects. There are, therefore, the inevitable (though occasional) " back and forth" movements in our argumentation. It is only to be hoped that in spite of such switches, we have managed to retain a degree of coherence in the chain of reasoning.

${ }^{4}$ We do not go into a discussion of the issue of whether and under what circumstances growth leads to overall material development as this has been extensively discussed in the literature (see Peter Bartelmus (2008) for a recent update ). Broadly speaking growth may be described as necessary but not sufficient for development.

5 . As Rostow (1971), p.268 puts it " governments take their shape legitimately only from some effective expression of the combined will and judgements of individuals". Of course, this does not imply that every individual is continuously involved with each aspect of government. Rather, individual preferences are sought to be articulated through a system of majority-elected representatives, based on political groups or parties (Cohen (1971), Ravich (2000) etc.).

${ }^{6}$ It is interesting to note that an essential ingredient in the perceived benevolent link between free markets and democracy is a strongly-held belief in the virtues of competition in both economic and political markets (e.g. Hayek (1960), Friedman (1963) etc.)

${ }^{7}$ None of the writers staking this claim have clarified the version of capitalism that they are talking about. But implicitly they seem to have the ideal version at the back of their minds.

${ }^{8}$ Schumpeter, however, also recognized certain important inconsistencies and contrary impulses within the two systems.

${ }^{9}$ To quote Weitzman (op. cit.) again "Capitalism is a market place of goods and democracy is a market place of ideas".

${ }^{10}$ The following quotation from Friedman (1963) is the most explicit statement of this viewpoint. 'History suggests only that capitalism is a necessary condition for political freedom. Clearly it is not a sufficient condition. Fascist Italy and Fascist Spain, Germany at various times in the last seventy years, Japan before World Wars I and II, tzarist Russia in the decades before World War $I$-- are all societies that cannot conceivably be described as politically free. Yet, in each, private enterprise was the dominant form of economic organization. It is therefore clearly possible to 
have economic arrangements that are fundamentally capitalist and political arrangements that are not free' (Friedamn (1963), Chapter 1). I am grateful to Pranab Bardhan for bringing this point to my notice.

${ }^{11}$ The DSM theorem has been refined and formalized through the successive writings of Debreu (1974), Sonnenschein (1974) and Mantel (1974). A brief explanation may run as follows. The foundations of neoclassical economics rest on the assumption that if individual demand functions satisfy Wald's (1936) WARP (weak axiom of revealed preference) (implying individual demand curves are downward sloping) then a unique stable market equilibrium exists. The DSM theorem asserts that whereas the WARP is sufficient to ensure the existence and local uniqueness (of a market equilibrium), global uniqueness and stability are not ensured by WARP (or by even stronger restrictions on individual demand functions) (see Kemp \& Shimomura (2002) for example). In spite of Hahn's (1975) admission that the DSM results are "most damaging to neoclassical theory", the mainstream economics profession has largely ignored these implications, (plausible reasons for this neglect are discussed in Hodgson (1997) and Rizvi (1994)).

${ }^{12}$ Moore (1966) also indicates that where the landed aristocracy was able to resist modernization by containing and dominating the rising commercial classes as in Germany and Japan, industrial capitalism gave rise to fascism..

${ }^{13}$ While analysts (e.g. Chadda (1997), Shapiro (1993) etc.) usually tend to favour the elite bargaining school as providing a better explanation of South Asian democratic patterns (as compared to structuralism) attention has also been drawn to an important common limitation shared by the two schools of thought. This derives from the common failing of attempting to apply concepts derived from Western democratic traditions to countries with vastly differing political and economic histories. Such a view leads them, for example, to view primordial identities (such as those based on religion, ethnicity, language, caste etc.) as inimical to democratic development (e.g. Kohli (1997)). As Lijphart $(1996,1999)$ has shown in his important work on consociational democracy, such identities have not prevented countries like India from evolving a consensual power-sharing arrangement among the various identity groups.

${ }^{14}$ Kraay (2005), for example, has shown that poverty changes in any country can be decomposed into three ingredients : (i) growth in per capita income (ii) elasticity of poverty reduction with respect to growth and (iii) changes in income distribution. Using a cross-country sample, Kraay finds that about $70 \%$ of the medium term variation (and $95 \%$ of the long-term variation) in headcount poverty changes is attributable to the growth factor alone, with the other factors playing a marginal role.

${ }^{15}$ Lopez \& Serven (2006) have given several illustrations of growth objectives in conflict with the poverty reduction and equity objectives. Among the important trade offs that they identify are the following : (i) higher spending on poverty related projects (rural infrastructure and housing, education, health etc.) versus the dictates of fiscal prudence (ii) capital account liberalization versus locking up of funds in forex reserves and (iii) protecting property rights of peasants versus the creation of SEZs for foreign investors. 
${ }^{16}$ There are annual surveys based on a thin sample of 4 households per village/urban block as also the quinquennial surveys based on a thick sample of 8 to 10 households per village/urban block.

${ }^{17}$ The poverty line used in the Table is as per the recommendations of an Expert Group set up by the Planning Commission in 1993. It uses a base poverty line of per capita consumption of Rs. 49 per month (rural) and Rs. 57 per month (urban), based on the recommended daily intake of 2400 calories (rural) and 2100 calories (urban). Adjustments are made to this base by using the CPI for agricultural workers in case of the rural line and the CPI for industrial workers for the urban poverty line.

${ }^{18}$ The fact that all-India poverty ratio has increased as between 1999-2000 and 2004-2005 is largely a reflection of the fact that the results of the $55^{\text {th }}$ NSS Round are not comparable with the results of the $50^{\text {th }}$ round. The methodology of the $61^{\text {st }}$ Round is however comparable to that of the $50^{\text {th }}$ Round (and hence not with that of the $55^{\text {th }}$ Round).

${ }^{19}$ Interestingly some tentative calculations extrapolating the Tendulkar methodology to the earlier years reported in the press (see Patnaik (13 December 2009)) also posit a decline of $8.1 \%$ over the comparable 11 year span.

${ }^{20}$ The Poverty Gap Index refers to the proportionate shortfall of income of all the poor from the poverty line as expressed in per capita terms (for the entire population).

${ }^{21}$ For detailed explanations of the various concepts involved, see Hansda \& Ray (2006))

${ }^{22}$ According to one estimate, the unorganized sector accounted for $91.66 \%$ of the total employed labour force in 1999-2000.

${ }^{23}$ Or putting it more graphically since the work force is growing at about $1.2 \%$ annually, a $9.5 \%$ growth is necessary to keeping the growing workforce employed, without adding to the existing unemployment backlog.

${ }^{24}$ The Gini coefficient is a measure of inequality, with higher values of the coefficient indicating greater inequality.

${ }^{25}$ Galbraith \& Lu (1999) for example, document that in Latin America financial crises raised inequality by $73 \%$ and in the Asian crisis inequality rose by $62 \%$. Diwan (2000) also notes the marked permanent decline in labour shares following financial crises.

${ }^{26}$ In the early stages of development, it is reasoned that awareness of environmental concerns is typically low, and hence there is little public support for pollution taxes/standards. The relation is reversed after the crossing of a certain threshold level of income, and thenceforth societal demand for a cleaner environment rises.

${ }^{27}$ The 17 industries include aluminium, caustic soda, cement, copper, distillery, dyes, fertilizers, pesticides,leather, iron \& steel, pulp \& paper, sugar, zinc, chemicals, plastic, wood \& wood products, and electricity.

${ }^{28}$ Transparency International is barely over a decade old, the OECD Convention on Combating Bribery did not go on line till 1999 (OECD, 2003), and anti-money laundering initiatives are still in their infancy (Financial Action Task Force 2004, and Financial Services Authority, 2003)

${ }^{29}$ Outdated legal systems often mean that the financial component of the punishment is a small fraction of the total magnitude of the amount involved in the corrupt deal. Besides conviction itself is rare and in most countries (except China) prison sentences are light.

${ }^{30}$ Some of the perpetrators of the 1992 stock market scam acquired the status of heroes in the public imagination--witness the widespread demonstrations in support of Harshad Mehta in Mumbai around that time. 
${ }^{31}$ In a series of important contributions, Chua (1998) has argued that " the combined pursuit of marketization and democratization in the developing world is likely to catalyze ethnic tensions.." (Chua 1998, p. 6). Her reasons for this thesis is that markets often reinforce the economic dominance of certain ethnic minorities, pitting an economically dominant ethnic minority against a politically powerful but impoverished majority. While her thesis seems to apply to several countries in Africa, Latin America and Asia, its strict validity in the Indian context seems doubtful, where the sources of both communal and caste tension centre around historically inherited imbalances, the call for "affirmative action" from minorities and lower castes to redress these, and the strong backlash against the same from the communities left outside the scope of such affirmative actions.

${ }^{32}$ As Blinder, a noted American economist and one time U.S Central Banker, has aptly put it " the incessant din of market chatter ...(tempts policymakers) to deliver the policy that markets expected or demanded" (see Blinder (1997)).

${ }^{33}$ It is a redeeming feature that the situation is far better with respect to the organizations and institutes dealing with science and technology.

${ }^{34}$ Given the wide-ranging powers of these boards, they play a very important role in deciding loan policies and investments of financial institutions. Since the flow of funds in the economy is very largely at the disposition of the banking system, we are rapidly approaching a situation where the objectives of monetary policy and other official financial sector measures could be frustrated by coordination failures between the central bank and the financial institutions.

${ }^{35} \mathrm{Cf}$. Schumpeter (1943) " History clearly confirms ..... [that]....modern democracy rose along with capitalism, and in causal connection with it.....modern democracy is a product of the capitalist process"

${ }^{36}$ Of course the modern methodology is far more sophisticated and mathematical, as compared to that of the founding fathers of the doctrine, like Adam Smith, David Ricardo and J.S. Mill. 